\title{
DESIGN OF EXPERT SYSTEM FOR IDENTIFY OF ANXIETY DISORDERS USING FORWARD CHAINING
}

\author{
Finanta Okmayura ${ }^{1 *}$, Vitriani $^{2}$, Melly Novalia $^{3}$ \\ Informatics Education \\ University of Muhammadiyah Riau \\ finantaokmayura@umri.ac.id ${ }^{1 *}$ ), vitriani@umri.ac.id ${ }^{2}$, mellynovalia@umri.ac.id 3 \\ $\left.{ }^{*}\right)$ Corresponding Author
}

\begin{abstract}
Abstrak
Ansietas merupakan gangguan kecemasan berlebihan di dalam ilmu psikologi. Masyarakat pada dasarnya tidak sadar bahwa mereka kemungkinan memiliki gejala gangguan ansietas ini pada dirinya masing-masing. Dan jika tidak diterapi sesegera mungkin dapat mengganggu kondisi psikis seseorang. Kelihatannya remeh tetapi gangguan ini dapat menurunkan kinerja sehingga hal ini berdampak pada kehidupan seseorang. Untuk mengatasi masalah ini maka dari itu diperlukan suatu sistem pakar yang dapat mengidentifikasi gangguan ansietas menggunakan algoritma forward chaining. Sistem ini dirancang menggunakan pemodelan diagram UML (Unified Modelling Language). Tujuan dari pemodelan UML ini adalah untuk menggambarkan kebutuhan pengguna terhadap sistem dan hal apa saja yang dapat dilakukan oleh sistem, sehingga dengan adanya pemodelan UML ini terlihat seluruh gambaran sistem. Pemodelan UML untuk sistem pakar identifikasi dini gangguan ansietas dengan algoritma forward chaining ini diharapkan dapat menjadi suatu alat yang dapat membantu proses pembuatan sistem, dimana masyarakat dapat mengecek apakah dirinya menderita gangguan kecemasan atau tidak layaknya berkonsultasi pada seorang psikolog.
\end{abstract}

Kata kunci: UML, Sistem Pakar, Gangguan Ansietas, Algoritma Forward Chaining

\begin{abstract}
Anxiety is an excessive anxiety disorder in psychology. People are basically not aware that they may have symptoms of this anxiety disorder in each of them. And if not treated as soon as possible can interfere with a person's psychological condition. It may seem trivial but this disorder can reduce performance so that it has an impact on a person's life. To overcome this problem, we need an expert system that can identify anxiety disorders using a forward chaining algorithm. This system is designed using UML (Unified Modeling Language) diagrammatic modeling. The purpose of this UML modeling is to describe the user's needs for the system and what things can be done by the system, so that with this UML modeling the entire system picture can be seen. The UML modeling for the expert system for early identification of anxiety disorders with the forward chaining algorithm is expected to be a tool that can assist the system creation process, where people can check whether they suffer from anxiety disorders or not to consult a psychologist.
\end{abstract}

Keywords: UML, Expert System, Anxiety Disorders, Forward Chaining Algorithm

\section{INTRODUCTION}

Anxiety is one of the disorders in psychology. Anxiety or anxiety is a condition of urgency that comes from outside the body, not from within. When this anxiety comes, it will make the person to do something (Calvin S. Hall \& Gardner Lindzey 2009). This anxiety is a symptom in the form of surprise at something that terrorizes humans accompanied by physiological changes (Asma 2014).

This anxiety is an excessive anxiety disorder that people sometimes don't realize about themselves. If not treated immediately, this disorder can interfere with a person's psychological condition and mobility. It may seem trivial but this disorder can reduce performance so that it has an impact on a person's life. Therefore we need an expert system identification of anxiety disorders to overcome this problem. Expert systems can solve a particular problem by imitating the way the experts work (Okmayura and Effendi 2019). With this expert system, the general public can consult with the system such as consulting a psychologist (Kanggeraldo, Sari, and Zul 2018). This expert system can also be used as a companion tool from experts (Kurniadi, Mulyani, and Rahayu 2021) and not to substitute the expert (Istiyawan and Wibisono 2020). Several studies have proven that expert systems with forward chaining algorithms 
are capable for diagnose lung disease (Anon 2016), stomach disease (Indah and Dewi 2019) and rubber plant disease (Rofiqoh, Kurniadi, and Riansyah 2020).

This system is designed using Unified Modeling Language (UML) diagram modeling. UML is an industry standard language for designing and visualizing and documenting system models (Pohan 2019). The purpose of this UML modeling is to be able to support automated analysis (Subhiyakto and Utomo 2017). In addition, this modeling aims to describe user needs for the system and what things can be done by the system, so that with UML modeling, the entire system picture can be seen. The UML modeling for the expert system for early identification of anxiety disorders is expected to be a tool that can assist the process of making the system, where people can check whether they suffer from anxiety disorders or not to consult a psychologist.

This UML modeling can describe an information system for monitoring the sale of goods stock (Ade Hendini 2016), lecturer remuneration information system design (Suendri 2018), sales information system design in building stores (Yunita 2018). In addition, modeling with UML has also succeeded in designing an employee performance reporting system (Putra 2018), printing product sales information system design (Aji et al. 2018). In the health sector, UML modeling has also been successful for the design of queuing software in health clinics (Syazili and Chandra 2018). In the world of education, UML modeling has also succeeded in designing a web-based school information system (Irawan, Susanti, and Triyanto 2016).

\section{RESEARCH METHODS}

The research methodology is a systematic step carried out during this research. For more details, the framework of this research can be seen in Table 1 below.

Table 1. Research Method

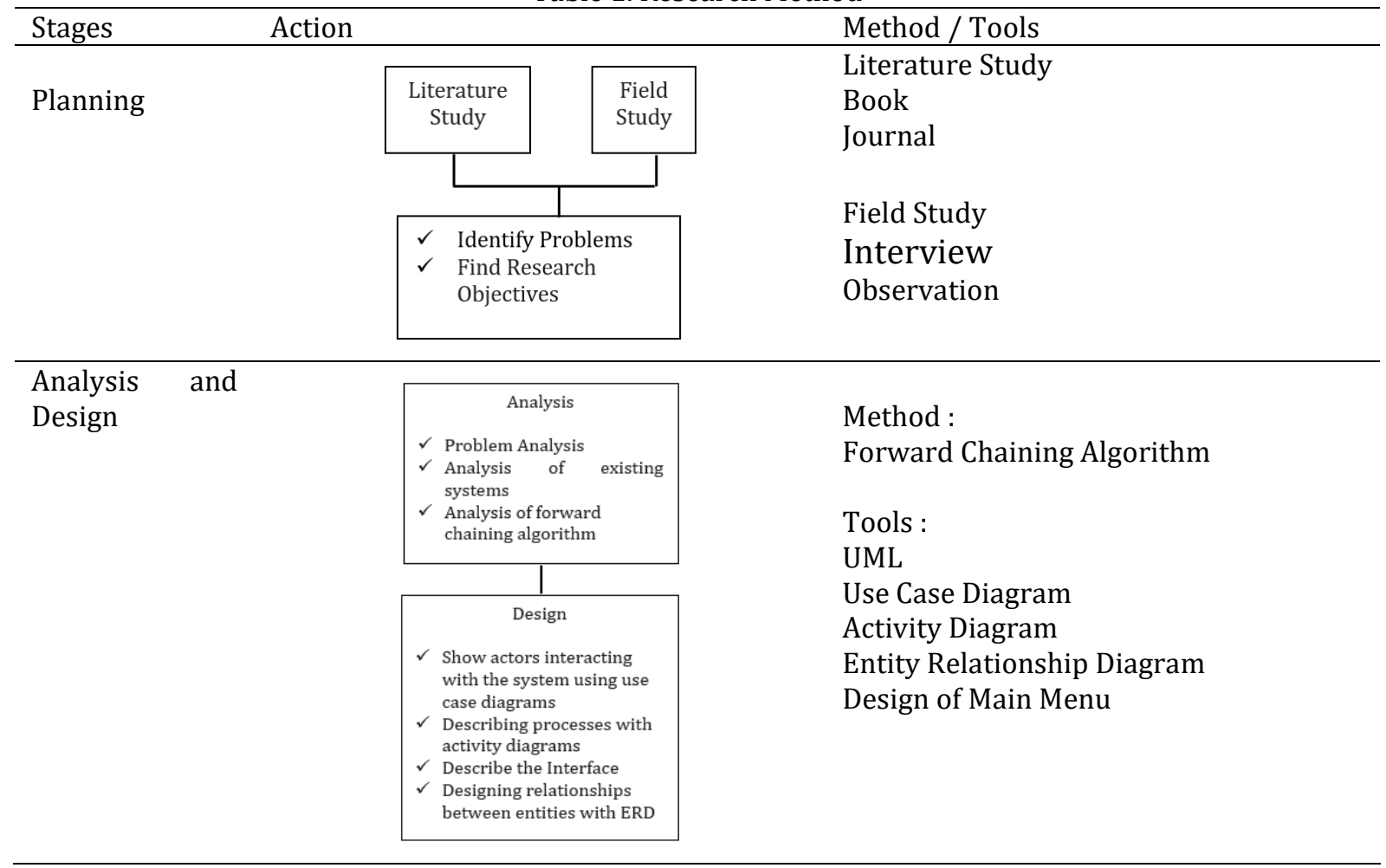

\section{RESULTS AND DISCUSSION}

\section{Planning}

\section{a. Literature Study}

Literature study is the initial stage of this research method. This method is carried out to obtain additional literature data from reference books regarding the problems raised in this study, namely the definition of expert systems, the use of the forward chaining method and various kinds of anxiety disorders and their symptoms sourced from books, journals, scientific papers. 


\section{b. Field Study}

In this research, the authors conducted direct interviews with two psychologists, namely Ummil Khairiyah, M.Psi, Psychologist and Sri Wahyuningsih, S.Psi, MA, M.Psi. From interviews obtained information related to anxiety disorders, symptoms and solutions. Anxiety disorders are divided into several parts, there are (Association 2004):

a. Panic attacks, this attacks start suddenly and cause worry, fear or terror. A person may have a feeling of impending doom, shortness of breath and chest pain

b. Agoraphobia, anxiety about trying to avoid, places or situations where a person might feel trapped or embarrassed to leave if they start having a panic attack.

c. Specific phobia, this phobia is characterized by significant anxiety when a person is exposed to a particular object or situation and a desire to avoid it

d. Social phobia, this phobia is characterized by significant anxiety triggered by exposure to some type of social or performance situation and a desire to avoid that fear.

e. Obsessive compulsive disorder, characterized by persistent, recurring anxiety, thought images or impulses or an irresistible desire (obsession) to perform an irrational act

f. Post traumatic stress disorder, this disorder is characterized by the feeling that a person is experiencing a very traumatic event again

g. Acute stress disorder, characterized by symptoms similar to those of post-traumatic stress disorder that occur immediately after a highly traumatic event

h. Generalized anxiety disorder, this disorder is characterized by excessive anxiety and worry about things big or small that persists for at least six months

\section{Analysis}

\section{a. Analysis of Existing Systems}

After making observations in the field, it turns out that many people in general do not realize that they can suffer from this anxiety disorder. Moreover, the costs required for consultation with a psychologist are also quite expensive. Therefore we need an application that can identify anxiety disorders early that can be used by ordinary people easily, namely with an expert system for early identification of anxiety disorders using a forward chaining algorithm. This algorithm works from cover to cover, meaning that the way it works is sequential, starting from questions from initial symptoms to more specific questions, resulting in onclusions about what disorders the user is suffering from.

\section{b. Analysis of Forward Chaining Algorithm}

This forward chaining algorithm is a search technique that matches the symptoms experienced by the user with anxiety disorders based on existing rules so that later what disturbances the user experiences. The matching process stops when no more rules can be executed. After the anxiety disorder is concluded, the expert system will recommend solutions or therapies that the user can take to overcome the disorder. For more details, the flowchart of the forward chaining algorithm for the identification of anxiety disorders can be seen in Figure 1 below.

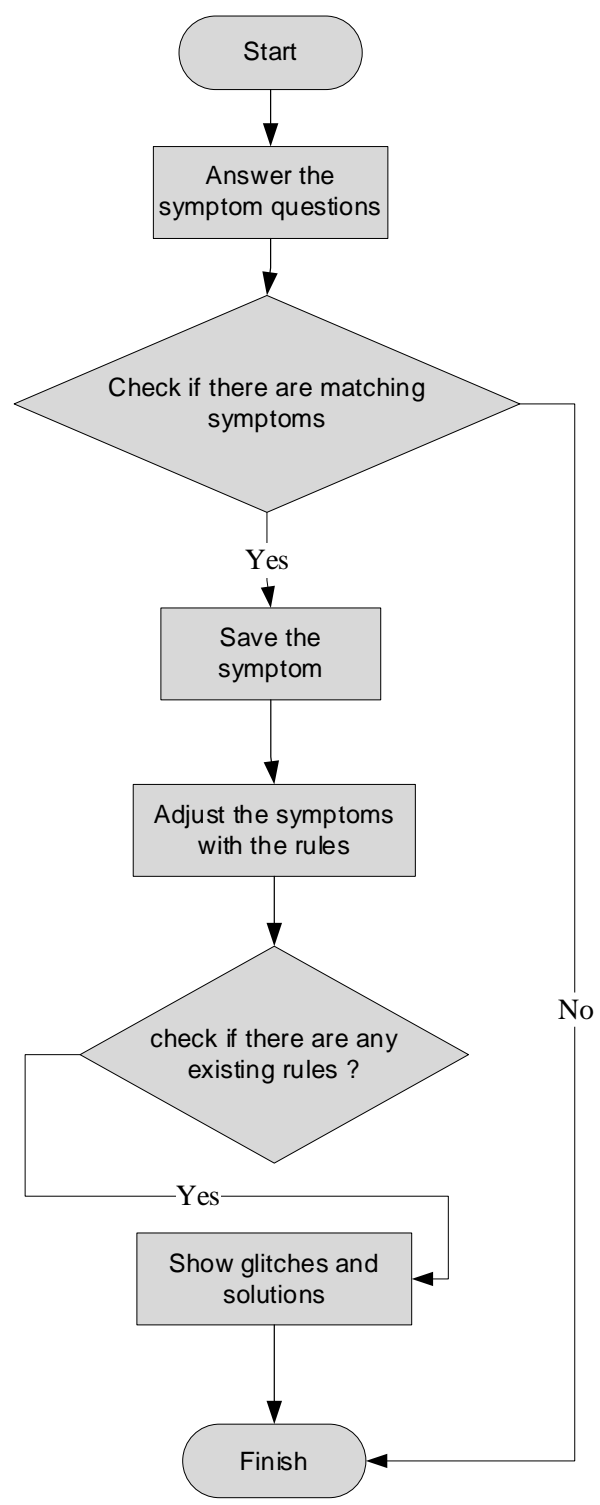

Figure 1. Flowchart Forward Chaining Algorithm 
The following is a table 2 for designing forward chaining algorithm rules for an anxiety disorder identification expert system.

Table 2. Forward chaining algorithm rules

No.

Rules

1. If Excessive anxiety is True

And Heart pounding is True

And Feeling worried and uncomfortable is True

And Feeling nauseous is True

And Shaky is True

And Feel dizzy is True

And Feeling pain in the chest is True

And Feeling hot and cold is True

And Afraid to die is True

And Experiencing shortness of breath

is True

$\underline{\text { And }}$ Panic or catastrophe will come

is True

Then Panic Attack

2. If Excessive anxiety is True

And Heart pounding is True

And Difficult to concentrate $\underline{\text { is True }}$

And Feeling worried and uncomfortable is True

And Excessive sweating is True

And Fear of losing control is True

And Experiencing anxiety when in a difficult situation is True

And Fear of being in a crowd

And Fear of being outdoors or traveling (in a bus, train or car) is True

And Often bring friends who will be with you when you feel panic $\underline{i s}$ True

Then Agoraphobia Disorder

3. If Kecemasan yang berlebihan is True And Difficult to concentrate is True $\underline{\text { And }}$ Feeling worried and uncomfortable is True

And Excessive sweating is True

And Fear of losing control is True

And Have you ever admitted that your fear is excessive and unwarranted is True

And At the age of under 18 years of experience at least 6 months of fear is True

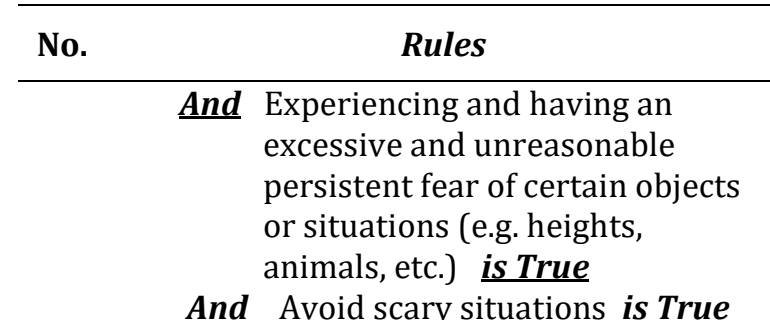

Then Specific Phobia

4. If Kecemasan yang berlebihan is True

And Difficult to concentrate is True

And Feeling worried and uncomfortable is True

And Excessive sweating is True

And Fear of losing control is True

And Have you ever admitted that your fear is excessive and unwarranted is True

And At the age of under 18 years of experience at least 6 months of fear is True

And Feeling constant fear of social situations leading to humiliating acts is True

And Experiencing stress or distraction in normal, routine situations is True

Then Social Phobia

5. If Kecemasan yang berlebihan is True

And Difficult to concentrate is True

And Feeling worried and uncomfortable is True

And Feeling worried and uncomfortable is True

And Recurrent and persistent thoughts, impulses, or urges that cause anxiety is True

And Repetitive mental behaviors and actions that a person performs to relieve tension is True

And Terus Constantly washing hands to remove dirt and germs $\underline{i s}$ True

And Doing things out of the ordinary is True

And Constant worry that something bad will happen to family members is True

And Fear of being dirty and exposed to germs or infections is True 


\begin{tabular}{cc}
\hline No. & \multicolumn{1}{c}{ Rules } \\
\hline & $\underline{\text { And }} \begin{array}{l}\text { Spouse's fear of getting into } \\
\text { danger while driving a vehicle } \underline{i s} \\
\text { True }\end{array}$
\end{tabular}

$\underline{\text { Then }}$ Obsessive compulsive disorder

6. If Kecemasan yang berlebihan is True

And Difficult to concentrate is True

And Feeling worried and uncomfortable is True

And Feeling worried and uncomfortable is True

And Responding with fear, helplessness is True

And Dreaming about recurring scary events is True

And Trying to avoid thoughts, feelings and conversations associated with the traumatic event is TruE

And Loss of interest in participating in various activities is True

And Perasaan away or isolated from others is True

And Feeling symptoms for more than one month lamanya is True

And Excessive vigilance $\underline{\text { is True }}$

And Surprisingly exaggerated response is True

Then Post Traumatic Disorder

7 If Kecemasan yang berlebihan is True

And Difficult to concentrate is True

And Feeling worried and uncomfortable is True

And Feeling worried and uncomfortable is True

And Feeling not in reality is True

And The feeling of feeling disconnected from oneself $\underline{\boldsymbol{i s}}$ True

And Responds with fear, helplessness is True

And Experiencing and witnessing events involving death threats is True

And Feelings of disconnection, numbness and lack of emotional response is True

And Decreased feeling of awareness of the surrounding environment is True

And Re-experiencing traumatic events through images, thoughts, dreams so that they

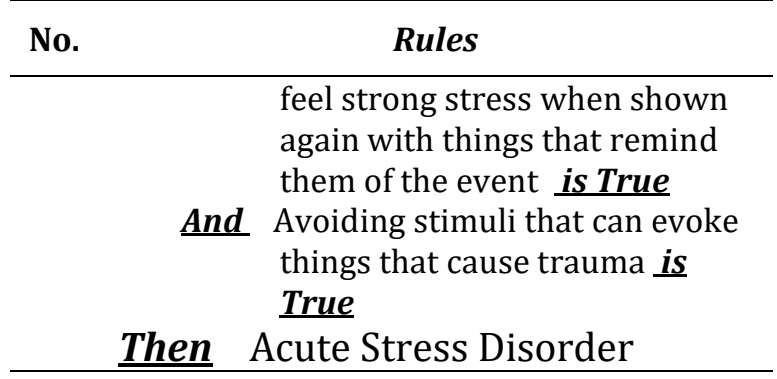

8. If Kecemasan yang berlebihan is True

And Difficult to concentrate is True

And Feeling worried and uncomfortable is True

And Feeling worried and uncomfortable is True

And Choking feeling is True

And Feeling nauseous is True

And Shaking is True

And Feel dizzy is True

And Other related worries and anxieties cause significant stress is True

And Have difficulty controlling feelings of anxiety is True

$\underline{\text { And }}$ Easily startled or startled $\underline{\text { is }}$ True

$\underline{\text { And }}$ Having trouble sleeping $\underline{\text { is True }}$

And Easily angry is True

$\underline{\text { And }}$ Experiencing tense muscles $\underline{i s}$ True

$\underline{\text { And }}$ Difficult to breathe normally $\underline{\text { is }}$ True

Then General Anxiety Disorder

\section{Design}

At this stage the researchers designed an expert system for identifying anxiety disorders using UML, starting from Use Case Diagrams, Activity Diagrams, Entity Relationship Diagrams and menu designs.

\section{a. Use Case Diagram}

Use Case Diagrams illustrate how users or actors can interact with the system (Okmayura et al. 2019). In the design of this system there are 3 actors who interact with the system, namely admin, psychologist and user. Admin can enter data in the form of symptoms, disorders, questions, solutions, probability values. Then the user can conduct consultations and psychologists can see the results of the medical records of users who have consulted on the system. More details can be seen in Figure 2 below. 


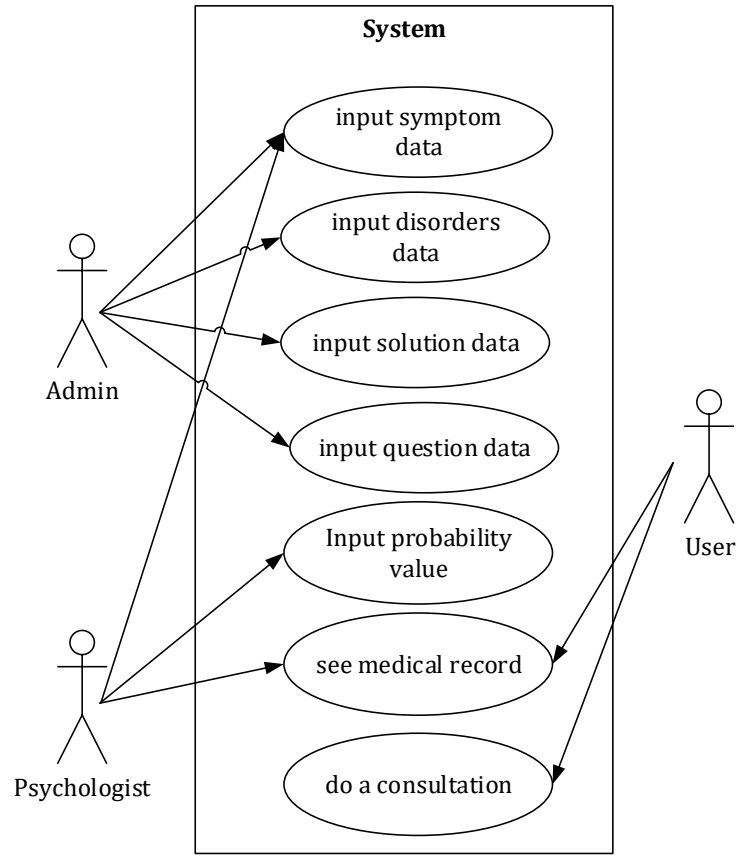

Figure 2. Use Case Diagram

\section{b. Activity Diagram}

Activity diagrams can be used to describe workflows or step-by-step activities in a system. Activity Diagram memiliki atribut dengan bentuk tertentu yang dihubungkan dengan tanda panah yang mengarahkan urutan aktivitas yang terjadi dari permulaan hingga akhir (Rizky Muhammad; Irma Kartika Wairooy, S.Kom. 2019).

This activity diagram shows how the overall control flow looks like. In this system, the user will enter the main page then the user must login. If the login fails, the user returns to the main page and if the user successfully logs in, the user will enter the identification page. Furthermore, the user identifies the anxiety disorder on himself independently. When finished, the identification result will appear. For more details, the activity diagram of this anxiety disorder identification system can be seen in Figure 3 below.

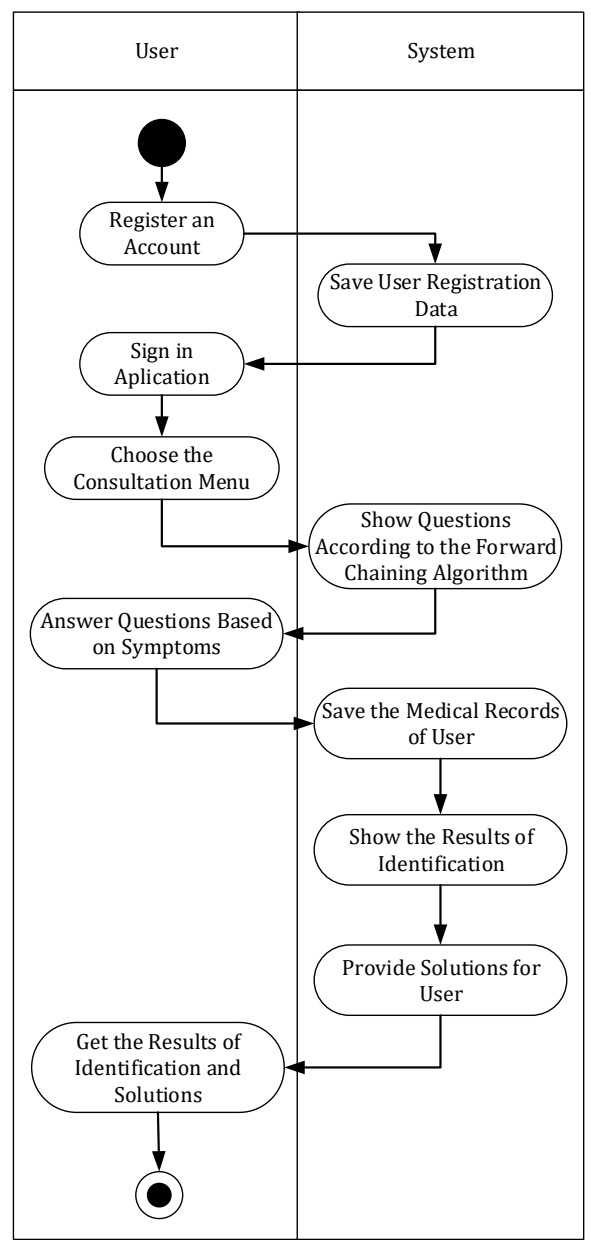

Figure 3. Activity Diagram

\section{c. Main Menu Design}

The design of the menu structure aims to present the arrangement of the menus in the system. The design of the expert system menu structure for the identification of anxiety disorders is shown in Figure 4 as follows.

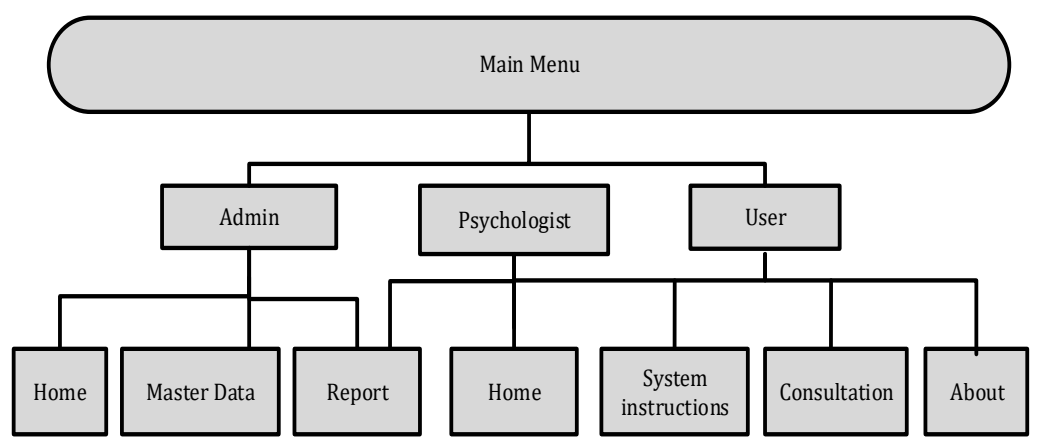

Figure 4. Design of Main Menu 


\section{d. Entity Relationship Diagram (ERD)}

Entity Relationship Diagram is a model diagram that aims to explain the relationship between data in a database that has a relationship between relationships (Ibeng 2018). In this expert system ERD there are several entities. For more details can be seen in Figure 5 below.

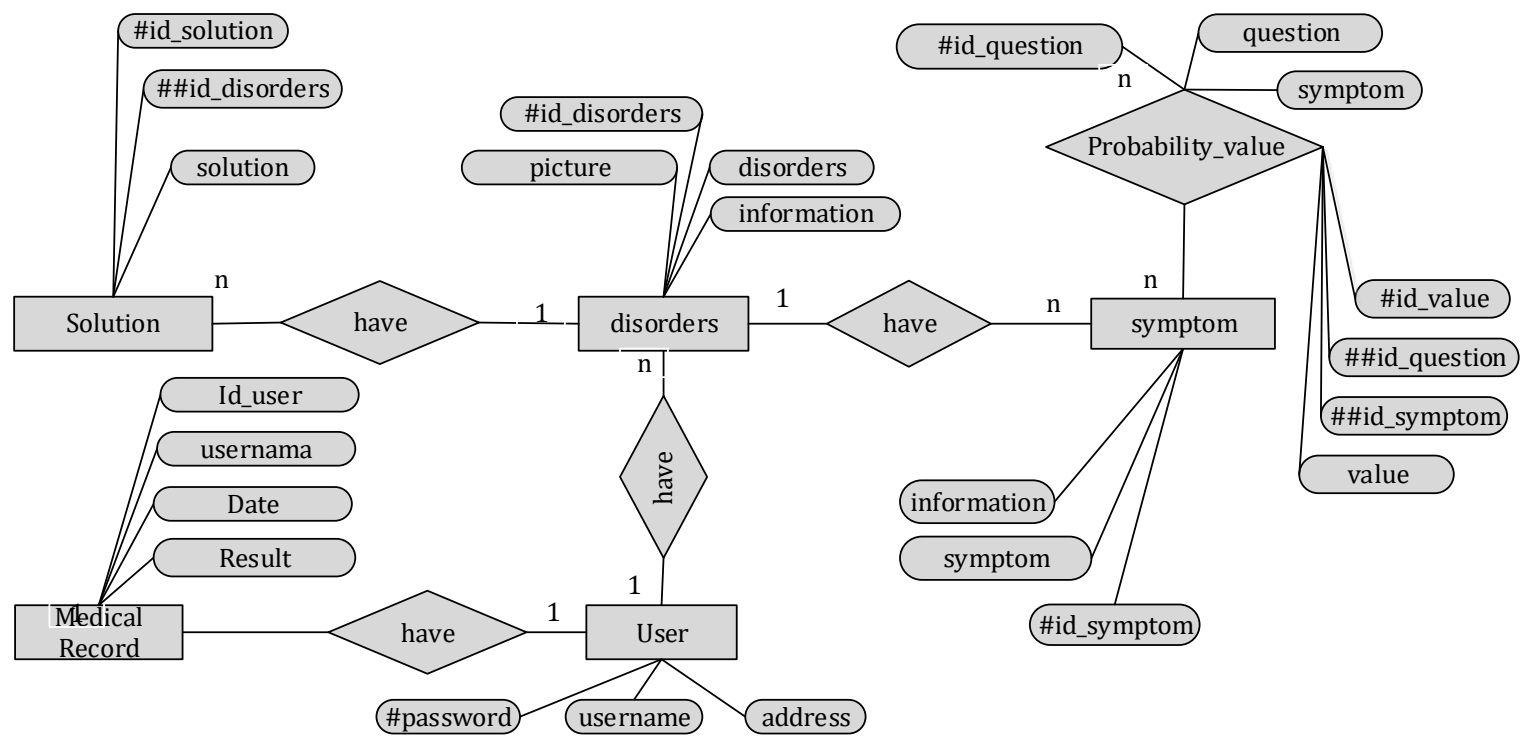

Figure 5. Entity Relationship Diagram

Based on Figure 5, the ERD which is designed in the expert system for early identification of anxiety disorders has 5 entities, namely users, medical records, solutions, disorders and symptoms. Each entity has its own attributes. Between one entity and other entities are interconnected to form a single entity.

\section{CONCLUSIONS AND SUGGESTIONS}

\section{Conclusion}

Based on the research that has been done, modeling with UML can be used to design an expert system for identifying anxiety disorders with forward chaining algorithm. UML modeling with use case diagrams, activity diagrams, data flow diagrams and entity relationship diagrams is very easy for users in designing expert systems. With this UML modeling, the system to be built will be closer to the actual user needs because the user in this case is a psychologist who plays a direct role and is involved in analyzing system requirements.

\section{Suggestion}

This research is expected to help create an expert system modeling for the identification of anxiety disorders, so that it can be used for the wider community. Then it is also hoped that modeling through the Unified Modeling Language can be developed also to design other information systems.

\section{REFERENCES}

Ade Hendini. 2016. "Pemodelan Uml Sistem Informasi Monitoring Penjualan Dan Stok Barang (Studi Kasus: Distro Zhezha Pontianak)." Jurnal Khatulistiwa Informatika $\operatorname{IV}(2)$.

Aji, Achmad Maezar Bayu, Verry Riyanto, Ganda Wijaya, and Biktra Rudianto. 2018. "Rancang Bangun Sistem Informasi Penjualan Produk Percetakan Berbasis Web Dengan Pemodelan UML." Indonesian Journal on Networking and Security 8(1).

Anon. 2016. "Sistem Pakar Diagnosis Penyakit ParuParu Menggunakan Metode Forward Chaining." Jurnal Teknik Elektro 8(2). doi: 10.15294/jte.v8i2.7436.

Asma, Nurul. 2014. "Pengaruh Konseling Terhadap Kecemasan Menghadapi Persalinan Pada Primigravida Di Wilayah Kerja Puskesmas Buket Hagu Kecamatan Lhoksukon Kabupaten Aceh Utara." Universitas Sumatra Utara.

Association, American Phychiatric. 2004. Diagnostic And Statistical Manual of Mental Disorders. Arlington. 
Calvin S. Hall \& Gardner Lindzey. 2009. Teori-Teori Psikodinamik. Yogyakarta: Kanius.

Ibeng. 2018. "Pengertian Entity Relationship Diagram (ERD).” Www.Pendidikanku.Org xii(33):43.

Indah, Malita, and Sarini Vita Dewi. 2019. "Rancangan Sistem Pakar Mendiagnosa Penyakit Lambung Menggunakan Metode Forward Chaining." Journal Of Informatics And Computer Science 4(2). doi: 10.33143/jics.vol4.iss2.541.

Irawan, Yudie, Nanik Susanti, and Wiwit Agus Triyanto. 2016. "Analisa Dan Perancangan Sistem Informasi Sekolah Berbasis Website Untuk Penyampaian Informasi Sekolah Dan Media Promosi Kepada MasyarakaT." Simetris: Jurnal Teknik Mesin, Elektro Dan Ilmu Komputer 7(1). doi: 10.24176/simet.v7i1.512.

Istiyawan, Diyan Bagus, and Setyawan Wibisono. 2020. "Sistem Pakar Diagnosa Hama Penyakit Tanaman Talasbentul Dengan Metode Dempster-Sahfer." Jurnal Dinamika Informatika 11(2). doi: 10.35315/informatika.v11i2.8156.

Kanggeraldo, Jansen, Rika Perdana Sari, and Muhammad Ihsan Zul. 2018. "Sistem Pakar Untuk Mendiagnosis Penyakit Stroke Hemoragik Dan Iskemik Menggunakan Metode Dempster Shafer." Jurnal RESTI (Rekayasa Sistem Dan Teknologi Informasi) 2(2). doi: 10.29207/resti.v2i2.268.

Kurniadi, Dede, Asri Mulyani, and Sri Rahayu. 2021. "Implementasi Metode Forward Chaining Pada Sistem Pakar Diagnosis Keperawatan Penyakit Stroke Infark." AITI 17(2). doi: 10.24246/aiti.v17i2.104-117.

Okmayura, Finanta, and Noverta Effendi. 2019. "Design of Expert System for Early Identification for Suspect Bullying On Vocational Students by Using Dempster Shafer Theory." CIRCUIT: Jurnal Ilmiah Pendidikan Teknik Elektro 3(1). doi: 10.22373/crc.v3i1.4691.
Okmayura, Finanta, Noverta Effendi, Witri Ramadhani, and Adlian Jefiza. 2019. "Analysis and Design of Calories Burning Calculation in Jogging Using Thresholding Based Accelerometer Sensor."

Pohan, Sentosa. 2019. "Pemodelan Uml Untuk Menentukan Kelulusan Penerimaan Siswa Baru Berbasis Web." Jurnal Informatika 3(2). doi: 10.36987/informatika.v3i2.214.

Putra, Erid Ade. 2018. "Analisa Dan Perancangan Sistem Pelaporan Kinerja Pegawai Menggunakan Work System Framework Dengan Pemodelan UML." INTECOMS: Journal of Information Technology and Computer Science 1(2). doi: 10.31539/intecoms.v1i2.296.

Rizky Muhammad; Irma Kartika Wairooy, S.Kom., M. T. 2019. "UML Diagram : Activity Diagram." Https://Socs.Binus.Ac.Id/ 1.

Rofiqoh, Siti, Dedy Kurniadi, and Andi Riansyah. 2020. "Sistem Pakar Diagnosa Penyakit Pada Tanaman Karet Menggunakan Metode Forward Chaining." Rancang Bangun E-CRM Pada Pasar Murah Solo 1(1).

Subhiyakto, Egia Rosi, and Danang Wahyu Utomo. 2017. "RMTool; Sebuah Aplikasi Pemodelan Persyaratan Perangkat Lunak Menggunakan UML." Jurnal Nasional Teknik Elektro Dan Teknologi Informasi (JNTETI) 6(3). doi: 10.22146/jnteti.v6i3.328.

Suendri. 2018. "Implementasi Diagram UML (Unified Modelling Language) Pada Perancangan Sistem Informasi Remunerasi Dosen Dengan Database Oracle (Studi Kasus: UIN Sumatera Utara Medan)." Jurnal Ilmu Komputer Dan Informatika 3(1).

Syazili, A., and W. Chandra. 2018. "Pemodelan UML Untuk Perangkat Lunak Antrian Pada Klinik Kesehatan." Seminar Nasional Teknologi ....

Yunita, Fitri. 2018. "Rancang Bangun Sistem Informasi Penjualan Pada Toko Bangunan Att Menggunakan Metode Pemodelan UML." JUTI UNISI 2(1). doi: 10.32520/juti.v2i1.242. 